\title{
Biochar as soil amendment: impact on chemical properties and corn nutrient uptake in a Podzol
}

\begin{abstract}
A study was conducted to investigate the impact of biochar amendment on chemical properties and corn nutrient uptake in a sandy Podzol soil. Four rates of biochar $(0,5,10$, and $15 \mathrm{~g} \mathrm{~kg}-1)$ and two rates of inorganic fertilizer ( 0 and local recommendation rate for corn) were randomly applied to a completely randomized design with four replicates. Corn was grown for $45 \mathrm{~d}$ in a glasshouse using sandy Podzol. The increase in $\mathrm{pH}$ of the soil was concomitant with a decrease of exchangeable Al. The fertilized soil significantly increased total $\mathrm{N}$, with a concomitant decrease in soil $\mathrm{pH}$ due to a $\mathrm{N}$ nitrification. Positive changes did occur in the soil due to biochar application, leading to a significant increase in dry matter yield and corn height. Corn $\mathrm{N}$ and $\mathrm{K}$ uptakes were significantly increased by the addition of biochar, but the same was not true for $\mathrm{Ca}$ and $\mathrm{Mg}$. However, it was found that the concentrations of $\mathrm{N}, \mathrm{Ca}$, and $\mathrm{Mg}$ in the corn tissue were still lower than their critical level. Our results demonstrate that application of biochar alone is not able to supply enough nutrients for the healthy growth of corn.
\end{abstract}

Keywords: Empty fruit bunch biochar; Soil properties; Corn; NPK fertilizer; Podzol 